\section{Location of Retrograde Changes in the Nervous System Following Unilateral Sympathectomy in Sheep}

\author{
Janusz Welento \\ Department of Animal Anatomy, \\ Agricultural University, Lublin
}

\section{SUMMARY}

Following unilateral right sympathectomy in sheep, it was found on the strength of retrograde changes in the anterior cervical ganglion, the stellate ganglion and neuromeres $T h_{1}-T_{4}$ that there exists a connection between the cervical sympathetic trunk and the vagus nerve.

The present paper is a continuation of our studies on the location of retrograde changes in the nervous system following unilateral sympathectomy in sheep (5). Our previous investigations showed that a majority (85\%) of the fibres of the cervical sympathetic trunk run towards the anterior cervical ganglion, and about $15 \%$ of the fibres proceed from nerve cells situated nasal to the same ganglion. The available literature does not offer a full explanation of this fact. Some authors $(3,7)$ are of the opinion that the anterior cervical ganglion is joined by the fibres proceeding from the IX, X and XII nerve. The opponents of this opinion regard these fibres as sensory $(1,2,4)$ or sympathetic $(6)$. The objective of the present work was to obtain at least a partial elucidation of this question in sheep. We thought it also of interest to study transneuronic degeneration in the sympathetic system and the behaviour of the cells of origin of the sympathetic trunk after a longer time following sympathectomy.

\section{MATERIAL AND METHODS}

Five sheep of mixed breed, Polish long-wool type, were used. Four of them (I, II, III and IV) were subjected, under eunarcon anaesthesia, to right sympathectomy at the level of $\mathrm{C}_{5}$, at the point where the sympathetic trunk leaves the vagus nerve. During the operation, a $2 \mathrm{~cm}$ long portion of the sympathetic trunk, together with the middle cervical ganglion, was removed. To prevent regeneration, the ends of the severed trunk were compressed with silver clamps. One sheep (V) was used as control; it was subjected to a similar operation, but without sympathectomy, to eliminate retrograde changes in the nervous system produced by the operation itself.

Sheep I, II and V were slaughtered after 21 days and sheep III and IV after 380 days. The following ganglia were taken for examination; anterior cervical, stellatc, jugular, nodose, oticum, pterygopalatinum, ciliare and semilunare. The brain stem and the spinal cord between $T h_{1}$ and $T h_{4}$ were also examined. The material was fixed in alcohol, cut into serial sections 10 microns thick, and stained with Lauth's blue according to a modification of Nissl's method. The nerves which proceed from the anterior cervical ganglion were also studied, their transverse sections being stained according to Woelcke.

\section{RESULTS}

The jugular ganglion. The retrograde changes in this ganglion were different in the two experimental groups. In sheep I and II they were typical changes in the form of tigrolysis, displacement of the cell nucleus towards the periphery and weaker staining (Figure 1). In sheep III and IV, only large, distinct vacuoles were seen in some cells of the ganglion (Figures 2, 3). Such changes occurred only on the sympathectomized side.

The anterior cervical ganglion. In sheep I and II, the cells of this ganglion on the sympathectomized side were free from retrograde changes (Figure 4).

In sheep III and IV, the findings were typical of transneuronic degeneration (accumulation and shrinking of cells and their modified staining properties - Figure 5).

The stellate ganglion. The cells of this ganglion were free from retrograde changes in shhep III and $\mathrm{IV}$, but a number of cells were degenerate and atrophied in sheep I and II (as in our previous paper 5). Only fragments of some of these cells remained, others had disappeared completely.

The spinal cord. Changes found in the segment $\mathrm{Th}_{1}-\mathrm{Th}_{4}$ in sheep III and IV closely resembled those seen in the stellate ganglion (Figures 6, 7). Changes in sheep I and II were the same as described in the previous paper (5).

The nervus caroticus internus. In all the sheep a myelinated fasciculus was found in this nerve (Figure 8), which proves that the nervus caroticus internus contains a fasciculus of fibres which run from the front to the rear in the anterior sympathetic trunk (5).

No retrograde changes were observed in the brain stem or in the remining ganglia.

\section{CONCLUSIONS}

1. In the sheep the cells of the jugular ganglion send fibres to the cervical sympathetic trunk.

2. After severing the sympathetic trunk, the cells of its origin undergo complete disintegration within a year.

3. After severing the cervical sympathetic trunk, the cells of the cervical sympathetic ganglion undergo transneuronic degeneration. 


\section{REFERENCES}

Cleveland, D. (1932): Afferent fibres in the cervical sympathetic trunk, superior cervical ganglion and internal carotid nerve. J. Comp. Neurol. 54, 35.

Edgeworth, M. B. (1892): On a large-fibred sensory supply of the thoracic and abdominal viscera. J. Physiology 13, 260.

Funaoka, S. (1926-1927): Über den Verlauf der markhaltigen Nervenfasern im Halssympathicus bei der Katze. Acta Scholae med. Kiot. 9, 377

Langley, M. A. (1892): On the larger medullated fibres of the sympathetic system. J. Physiology, 13, 786.
Milart, Z. J.-J. Welento (1967): Retrograde changes in the Nervous System Following Unilateral sympathectomy. Zbl. Vet. Med., A, 14, 510.

Murat, W. N. (1952): On the ganglion pterygopalatinum. Arch. Anat. Histo. Embr. 19, 7.

Uchida, S. (1927-1928): Morphologische Studien des sympathischen Nervensystems des Schweins (Sus asiaticus). Acta Schlae Med. Kioto. 10, 235.

Figure 1: Degenerate cell of the ganglion jugulare, sheep I. Lauth blue. $\times 225$

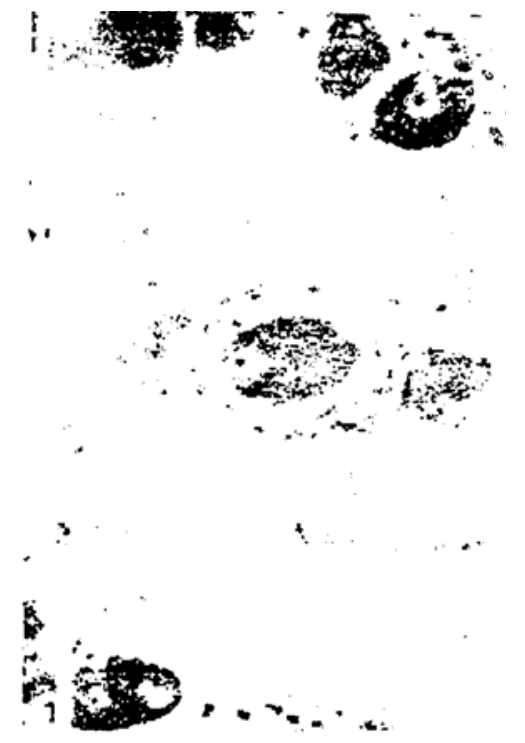

Figures 2 and 3: Vacuolated cells of the ganglion jugulare, sheep III. Lauth blue. $\times 225$
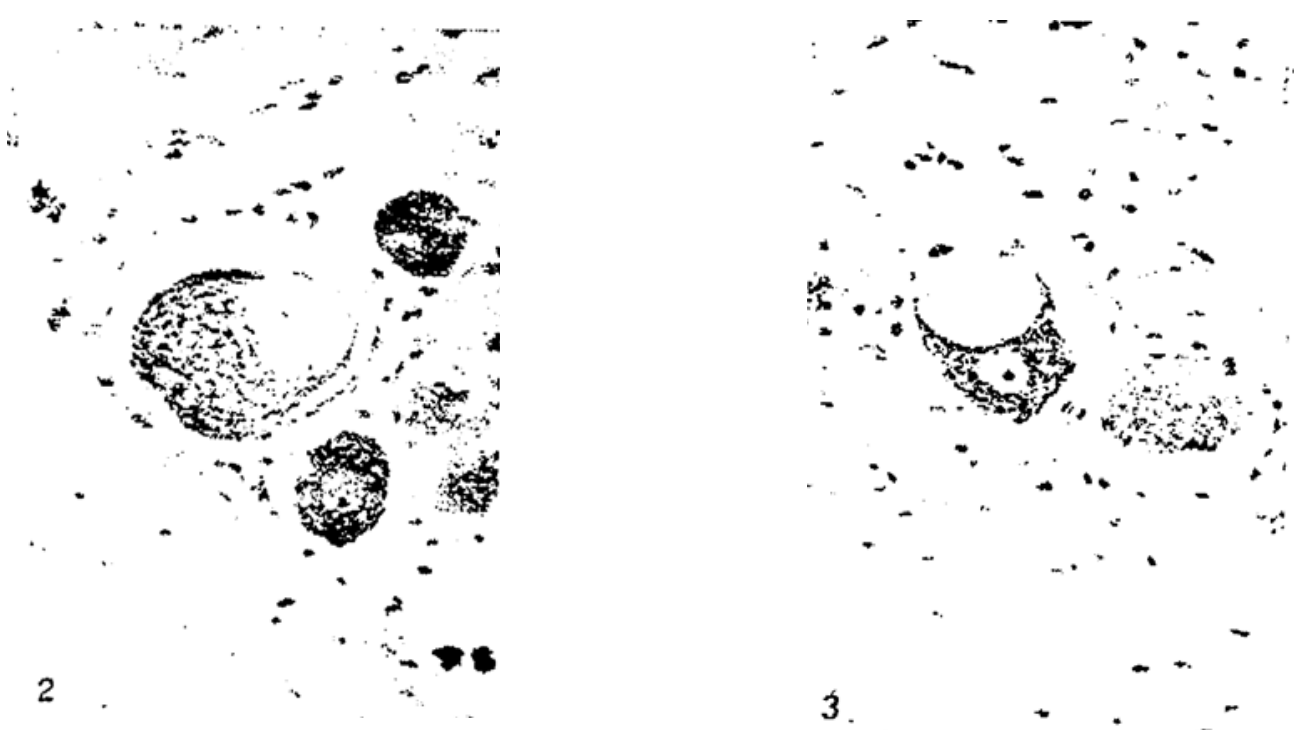
Figure 4: Normal cells of left anterior cervical ganglion, sheep III. Lauth blue. × 225

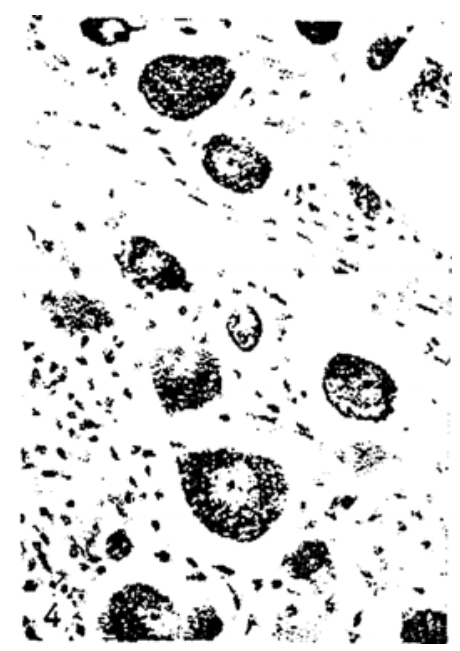

Figure 5: Degenerate cells of right anterior cervical ganglion, sheep III. Lauth blue. $\times 225$

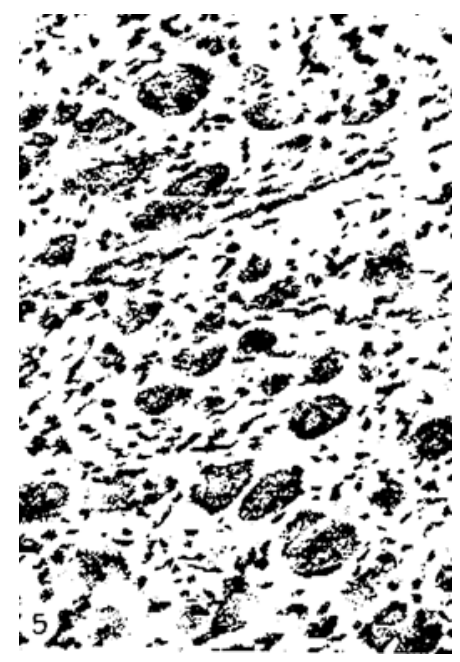

Figure 6: Nerve cells of left lateral horn $\left(\mathrm{Th}_{2}\right)$, sheep III. Lauth blue. $\times 195$

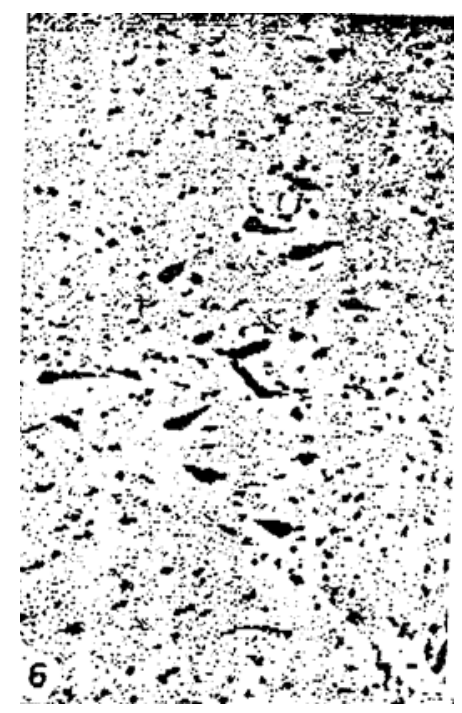


Figure 7: Nerve cells of right lateral horn $\left(\mathrm{Th}_{2}\right)$, sheep III. Lauth blue. $\times 195$

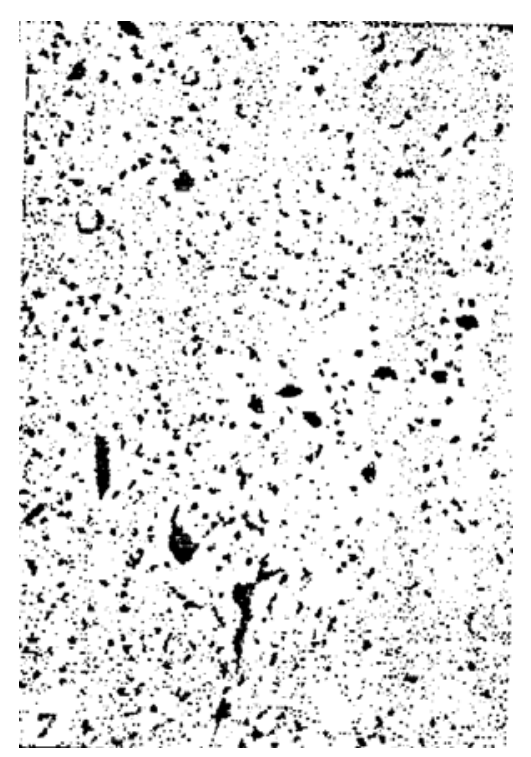

Figure 8: Myelinated fasiculus in the nervus caroticus internus, sheep III. Woelcke method. $\times 225$

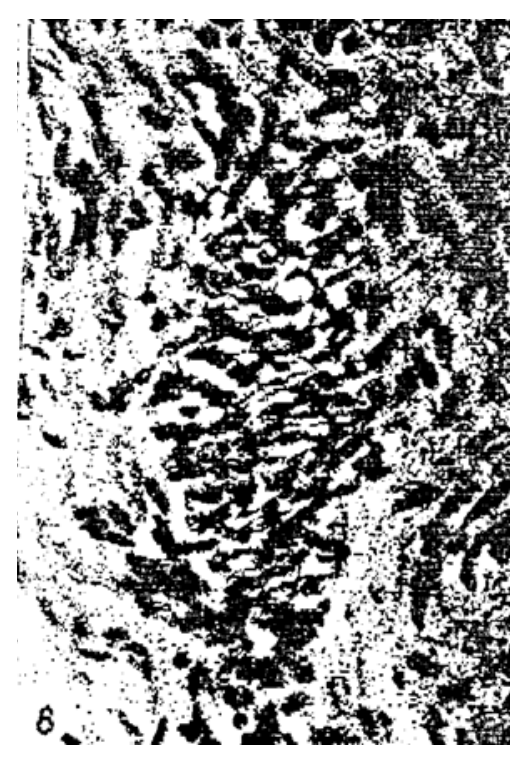

